\title{
PESQUISA DE OOCISTOS DE CRYPTOSPORIDIUM SP EM FEZES: COMPARAÇ̃̃O ENTRE OS MÉTODOS DE KINYOUN MODIFICADO E DE HEINE
}

\author{
Vicente Amato Neto, Lúcia Maria Almeida Braz, Andréia Otaviani Di Pietro \\ e José Rafael Módolo
}

\begin{abstract}
Para diagnosticar a infecção intestinal pelo Cryptosporidium sp, boje bastante em foco pela näo incomum participação no contexto da síndrome da imunodeficiência adquirida (AIDS), várias técnicas tên sido indicadas. Com o intuito de esclarecer vantagens e desiantagens, envolvendo quantificaçâo, morfologia, durabilidade do esfregaço e tempo de preparação, comparamos os resultados obtidos mediante emprego de dois desses processos, ou seja, de Kinyoun modificado e de Heine, aplicados em amostras fecais de pacientes com AIDS. A sensibilidade foi bastante semelhante e a escolba deve depender da valorização das virtudes de cada uma das técnicas, que são: quanto à de Kinyoun modificada, a durabilidade dos esfregaços e, a propósito da de Heine, a rapidez com que se dá o preparo, aliada à superioridade quando o parâmetro é a quantidade de oocistos encontrados, mais freqüentemente verificada.
\end{abstract}

Palauras-chates: Cryptosporidium sp. Diagnóstico. Exame de fezes. Métodos de Kinyoun modificado e de Heine. Comparação.

De distribuição cosmopolita, o Cryptosporidium sp, coccídeo implicado em doença intestinal, é detectado conforme freqüência de aproximadamente $10 \% \mathrm{em}$ pacientes com a síndrome da imunodeficiência adquirida (AIDS) nos Estados Unidos da América e de 30 a 50\% nos países em desenvolvimento ${ }^{8}$. Guizelini, no Brasil, por exemplo, encontrou taxa de $21,2 \%$ em doentes com tal afecção e diarréia, atendidos no Hospital das Clínicas, da Faculdade de Medicina da Universidade de São Paulo'.

Esse agente zoonótico é responsável por acometimento gastrintestinal autolimitado em individuos imunocompetentes e por vezes severo em imunodeficientes ${ }^{2}$.

Entre as técnicas de coloração mais utilizadas para a evidenciação desse parasita contamos com as de Giemsa, da auramina, de Ziehl-Neelsen e suas modificações, do dimetilsulfóxido, de Kinyoun e suas alterações, da safranina e de Heine ${ }^{67}$. Também têm sido utilizados anticorpos monoclonais para a pesquisa dos oocistos nas fezes ${ }^{135}$.

Laboratório de Investigação Médica-Parasitologia, do Hospital das Clínicas, da Faculdade de Medicina da Universidade de São Paulo, São Paulo, SP.

Endereço para correspondência: Prof. Vicente Amato Neto. Av. Dr. Enéas de Carvalho Aguiar 500, 05403-000 São Paulo, SP. Fax: (011) 852-3622

Recebido para publicação em 05/11/95.
Mais comumente empregamos o método modificado de Kinyoun, que tem base na propriedade de ácido-resistência do coccídeo. Mais recentemente passamos a recorrer também à coloração negativa de Heine ${ }^{47}$. Para tentar contribuir quanto ao diagnóstico dessa parasitose por meio do exame de fezes, empreendemos o estudo agora relatado a fim de. avaliar vantagens e desvantagens desses dois modos de proceder, envolvendo quantificação, morfologia, durabilidade de lâmina e tempo de preparação.

\section{MATERIAL E MÉTODOS}

Examinamos 53 amostras de fezes, de pacientes com AIDS, assistidos na Divisão de Clínica de Moléstias Infecciosas e Parasitárias, do Hospital das Clínicas, da Faculdade de Medicina da Universidade de São Paulo, sendo os exames pedidos para obter ou confirmar diagnósticos e controlar tratamentos. De cada uma, analisamos $3 \mu 1$ de fezes em cada lâmina e para cada técnica, conforme procedimentos a seguir especificados.

Método de Kinyoun modificado: após fixação com metanol, coramos o esfregaço de $3 \mu l$ por meio da fucsina carbólica, durante 15 minutos; lavamos em água corrente, descoramos com ácido-sulfúrico a $10 \%$ por a proximadamente três minutos e, novamente, lavamos em água 
Amato Neto V, Braz LMA, Di Pietro AO, Módolo JR. Pesquisa de oocistos de Cryptospotidium sp em fezes: comparação entre os mêtodos de Kinyoun modificado e de Heine. Revista da Sociedade Brasileira de Medicina Tropical 29:575-578, nov-dez, 1996.

corrente; cobrimos a lâmina com azul de metileno a $1 \%$, no decurso de cinco minutos; por fim, lavamos e secamos.

Método de Heine: adicionamos $3 \mu 1$ de fucsina carbólica de Ziehl a 3ul do esfregaço e juntamos uma gota de óleo de imersão e lamínula, após secagem.
Ulteriormente às colorações, de acordo com o que descrevemos, realizamos as pesquisas efetuando quantificação em microscópio óptico, por intermédio de objetivas para aumentos de $1000 \mathrm{x}$ (imersão) e $400 \mathrm{x}$ a propósito dos processos de Kinyoun modificado e de Heine, respectivamente.

\section{RESULTADOS}

Em 41 das 53 amostras de fezes estava presente o parasita. A técnica de Kinyoun permitiu o encontro de oocistos em 39 e a de Heine em 38, havendo duas negatividades ao ser aplicada a primeira e três quando empregada a outra. Sempre que um processo falhou o Cryptosporidium sp ficou demonstrado pelo considerado na comparação.

A respeito da quantidade de oocistos constatamos: superioridade do método de Kinyoun - 14; superioridade no método de Heine - 26; números iguais - 1 (Tabela 1).

Tabela 1- Quantidades de oocistos de Cryptosporidium sp encontrados nos exames efetuad

\begin{tabular}{|c|c|c|}
\hline Amostra & Kinyoun modificado & Heine \\
\hline 1 & $\overline{11}$ & 48 \\
\hline 2 & 26 & 107 \\
\hline 3 & 9 & 0 \\
\hline 4 & 57 & 0 \\
\hline 5 & 1 & 81 \\
\hline 6 & 41 & 145 \\
\hline 7 & 642 & 345 \\
\hline 8 & 43 & 158 \\
\hline$\cdot 9$ & 8 & 252 \\
\hline 10 & 58 & 90 \\
\hline 11 & 14 & 62 \\
\hline 12 & 345 & 645 \\
\hline 13 & 13 & 124 \\
\hline 14 & 69 & 29 \\
\hline 15 & 3 & 178 \\
\hline 16 & 0 & 15 \\
\hline 17 & 9 & 27 \\
\hline 18 & 118 & 251 \\
\hline 19 & 1 & 3 \\
\hline 20 & 12 & 41 \\
\hline 21 & 0 & 2 \\
\hline 22 & 2 & 71 \\
\hline 23 & 158 & 551 \\
\hline 24 & 5 & 0 \\
\hline 25 & 98 & 197 \\
\hline 26 & 20 & 21 \\
\hline 27 & 11 & 27 \\
\hline 28 & 2 & 13 \\
\hline 29 & 13 & 81 \\
\hline 30 & 33 & 18 \\
\hline 31 & 262 & 69 \\
\hline 32 & 3 & 65 \\
\hline 33 & 10 & 6 \\
\hline 34 & 21 & 59 \\
\hline 35 & 17 & 8 \\
\hline 36 & 23 & 44 \\
\hline 37 & 160 & 20 \\
\hline 38 & 198 & 152 \\
\hline 39 & 73 & 38 \\
\hline 40 & 149 & 38 \\
\hline 41 & 373 & 182 \\
\hline
\end{tabular}

O método de Kinyoun mostra protozoário esférico e vermelho, possibilitando diferenciálo de leveduras, mas restos fecais podem causar confusão com oocistos se o examinador não for suficientemente habilitado (Figuras $1 \mathrm{e}$ 2); ainda mais, é viável a existência de oocistos

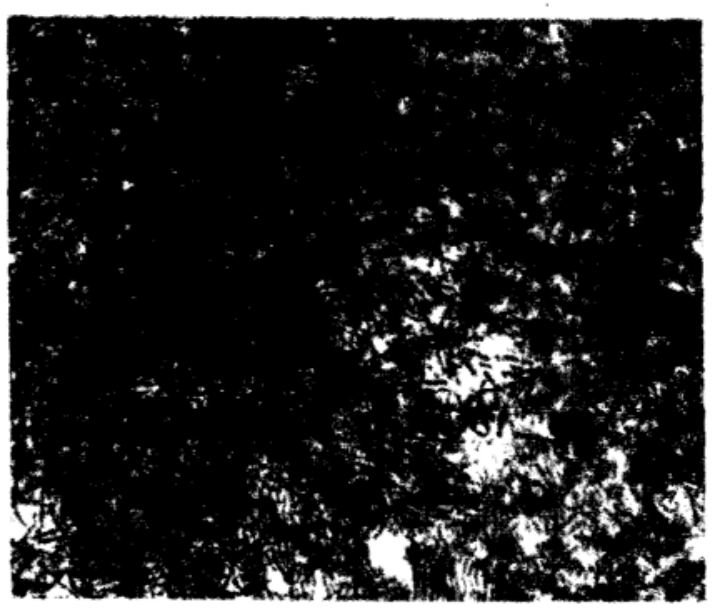

Figura 1 - Oocistos do Cryptosporidium sp corados pelo metodo de Kinyoun modificado (1000X).

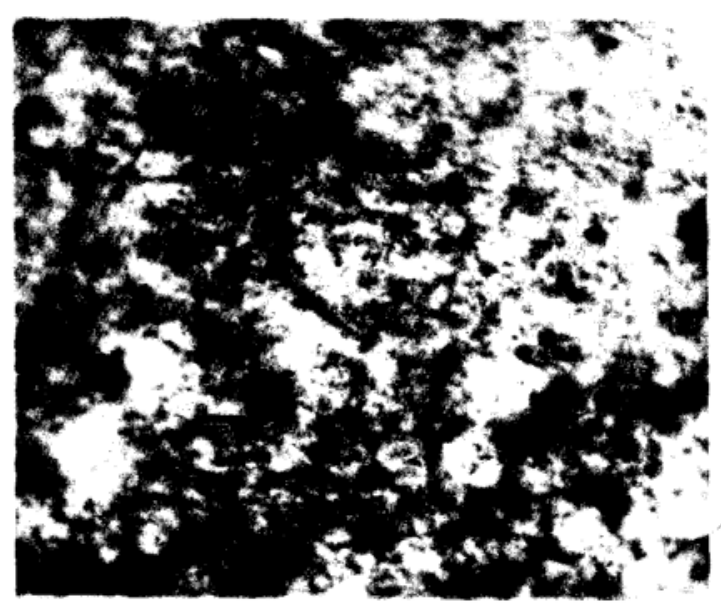

Figura 2 - Restos fecais corados pelo método de Kinyoun modificado $(1000 \mathrm{X})$. 
Amato Neto V, Braz LMA, Di Pietro AO, Módolo JR. Pesquisa de oocistos de Cryptosporidium sp em fezes: comparação entre os métodos de Kinyoun modificado e de Heine. Revista da Sociedade Brasileira de Medicina Tropical 29:575-578, nov-dez, 1996.

"fantasmas", não corados e a esse inconveniente somamos o tempo gasto, de aproximadamente 25 minutos, na coloração (Figura 3). Por seu turno, à técnica de Heine sucede o que se admite interpretar como coloração negativa, vendo-se oocistos acromáticos e com brilho característico, sete minutos após o início da execução (Figura 4); contudo, depois de 30 minutos a visualização da morfologia torna-se prejudicada.

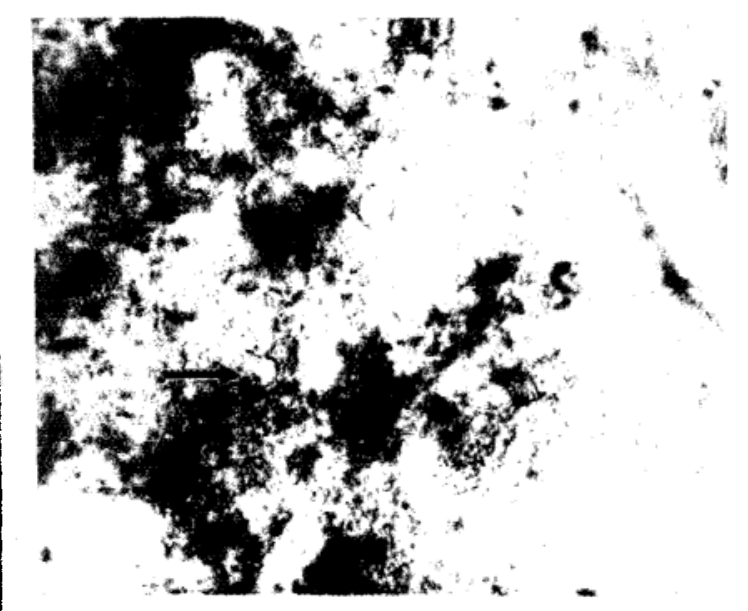

Figura 3 - Oocistos "fantasmas" do Cryptosporidium sp encontrados em exame efetuado pelo metodo de Kinyoun modificado (1000X).

Figura 4 - Oocistos do Cryptosporidium sp visualizados ao exame pelo método de Heine ( $400 \mathrm{X})$.

\section{DISCUSSÃO}

O grande e crescente número de indivíduos infectados pelo vírus da imunodeficiência humana (HIV), que motiva o desencadeamento da AIDS, faz com que a criptosporidiase seja atualmente parasitose merecedora de cogitação em múltiplas oportunidades, pois o Cryptosporidium $s p$ muitas vezes compõe a síndrome em apreço. Em geral o diagnóstico dessa protozoose depende do exame das fezes, executado por intermédio de procedimentos em geral simples. $O$ uso de anticorpos monoclonais sem dúvida concede maiores sensibilidade e especificidade, não podendo porém ter aplicação ampla, como decorrência do elevado custo, quase sempre proibitivo em países do terceiro mundo.

Nos últimos anos o interesse pela pesquisa do parasita nas fezes aumentou bastante e as qualidades de diferentes técnicas passaram a ser objetos de especulações e, nesse âmbito, procuramos contribuir, comparando os resultados obtidos quando empregados os métodos de Kinyoun modificado e de Heine. Notamos que aquele revelou uma positividade a mais, de molde a evidenciar superioridade, não marcante; todavia, em maior porção de ocasiões mostrou números menores de oocistos e para tanto é possível que influam o procedimento de descoloração, além da posterior lavagem em água, favorecendo a soltura de parte do esfregaço. No que tange ao outro processo, as virtudes destacáveis são a rapidez com que se dá o preparo e a superioridade quando o parâmetro é a cifra de oocistos encontrados, mais freqüentemente verificada.

A durabilidade do esfregaço é atributo do processo de Kinyoun modificado, capaz de favorecer a natureza de tarefas específicas e possibilitar exame de diversas lâminas, aumentando assim a sensibilidade.

Expostas essas averiguações, cremos que se torna correto afirmar que a escolha terá vínculo com a valorização das melhores qualidades de cada um dos métodos, na dependência das circunstâncias em que tarefas diagnósticas deverão ocorrer.

\section{SUMMARY}

The diagnosis of intestinal infection by Cryptosporidium sp is crucial today; with the progression of the AIDS epidemic, many cases of cryptosporidiosis bave appeared in this setting and in other immunodeficiency diseases. We compared the advantages and disadvantages of Heine's 
Amato Neto V, Braz LMA, Di Pietro AO, Módolo JR. Pesquisa de oocistos de Cryptosporidium sp em fezes: comparação entre os métodos de Kinyoun modificado e de Heine. Revista da Sociedade Brasileira de Medicina Tropical 29:575-578, not'-dez, 1996.

method and modified Kinyoun's method in the following parameters: morphology of the parasite, quantitation of cysts, stability of the staining characteristics timeuise on the slides and time spend at staining. All positive fecal smears uere obtained. from patients with AIDS. The sensitivity of these two techniques was the same. The choice should be made by the best aspects of each metbod. Heine's uas better for quantitation of the cysts and was faster. Kinyoun's was better for conseming the stained smear.

Key-uords: Cryptosporidium sp. Diagnosis of cryptosporidiasis. Stool tests for protozoa. Comparison of Heine's and Kinyoun's methods.

\section{REFERÊNCIAS BIBLIOGRÁFICAS}

1. Arrowood MJ, Sterling CR. Comparison of conventional staining methods and monoclonal antibody-based methods for Cryptosporidium oocyst detection. Journal of Clinical Microbiology 27:1490-1495, 1989.

2. Campbell PN, Current WL. Demonstration of serum antibodies to Cryptosporidium $s p$ in normal and immunodeficient humans with confirmed infections. Journal of Clinical Microbiology 18:165-169, 1983.
3. Garcia LS, Brewer TC, Bruckner DA. Fluorescence detection of Cryptosporidium oocysts in human fecal specimens by using monoclonal antibodies. Journal of Clinical Microbiology 25:119-121, 1987.

4. Guizelini E. Pesquisa de oocistos de Copptosporidium $s p$ nas fezes de pacientes com diarréia, mediante emprego de três técnicas de coloração. Dissertação de Mestrado. Instituto de Ciências Biomédicas da Universidade de São Paulo, São Paulo, 1991.

5. Loose JH, Sedergran DJ, Cooper HS. Identification of Cryptosporidium in paraffin-embedded tissue sections with the use of a monoclonal antibody. American Journal of Clinical Pathology 91:206209, 1989.

6. MacPherson DW, McQueen R. Cryptosporidiosis: Multiattribute evaluation of six diagnostic methods. Journal of Clinical Microbiology 31:198202, 1993.

7. Modolo JR, Gonçalves RC, Kuchembuck MRG, GottschalkAF. Ocorrência de criptosporidiose em bezerros na região de Botucatu - SP. Revista Brasileira de Medicina Veterinária 10:9-10, 1988.

8. Petersen C. Cellular biology of Cryptosporidium parzum. Parasitology Today 9:87-91, 1993. 